\title{
THE GEOLOGY AND PETROLOGY OF THE GREAT SERPENTINE BELT OF NEW SOUTH WALES.
}

\section{Part IX.-The Geology, Palaeontology and Petrography of the Currabubula District, with Notes on Adjacent Regions.}

\author{
By Professor W. N. Benson, B.A., D.Sc., F.G.S., W. S. Dun, and \\ W. R. Browne, B.Sc.
}

Section B.-Palaeontology.

By W. S. Dun, Government Palaeontologist and Lecturer in Palaeontology, The University of Sydney, and W. N. Benson, B.A., D.Sc., F.G.S., Professor of Geology, The University of Otago, N.Z.; formerly Linnean Macleay Fellow of the Society in Geology.

With an Appendix by F. Chapman, A.L.S., Lecturer in Palaeontology, The University of Melbourne.

(Plates xviii.-xxiv.; Text-figures 10-17.)

Descriptive portion (W. S. Dun and W. N. Benson) . . . . . . . . . . . . . . 337 Appendis.-Lower Carboniferous Limestone fossit; from New South Wales (F.

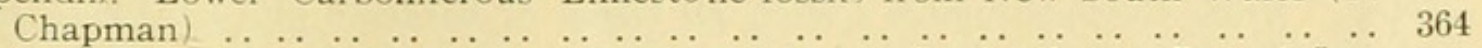
Comparison of the Burindi Fauna with the Lower Carboniferous Faunal Suc-

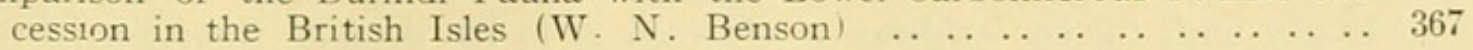

(i.) Descriptive Portion.

(W. S. Dun and W. N. Benson.)

In the following section we have remarked'upon the noteworthy features of all fossils obtained by us from Currabubula and the shelly ridge in the south-east of the parish of Babbinboon, and also the extensive collection from the latter area presented to us by Mrs. Scott, to whom we are greatly indebted. The opportunity has been taken to examine also the undescribed fossils in the collection of the Australian Museum and that of the Geological Survey which were obtained in the region around Carroll, Somerton and Babbinboon, chiefly by Mr. Donald Porter, and the late Charles Cullen. We are thus able to give a list of the known forms, including eritical descriptions of five forms previously known in the State but only from provisional determinations, seven new records for the State, and fifteen species and three varieties which we believe to be new. We are indebted to Professor Lawson, D.Se. and Mr. Chapman for the description of several of the fossils. Apart from the leaf impressions of Rhacopteris, Aneimites and Archaeocalamites in the Kattung, which do not eall for speeial notice, two silicified plant remains are noteworthy. They were found on the eastern slopes of Mts. Cobla and Sugarloaf, three miles east of Currabubula. Professor Lawson describes 
these as follows:- "The first is represented by a single specimen about four inches in either dimension; portion of a large stem of gymnospermous wood. The cellular structure shows no sharp definition; the tracheids may be made out rather vaguely, and these are traversed by numerous medullary rays, some of which are several cells in width, others only a single cell. Vague indications of bordered pits appear in the tracheids, but on account of the poor definition of the tracheids themselves, it is impossible to determine how many rows of these are present on the tracheid. From the evidence of their more or less eireular outline as seen on the radial wall, one is inclined to the conclusion that there is only a single row of these in each tracheid. The length of a single tracheid cannot be defined."

The second form is illustrated by two specimens possibly originally united; the one has roughly the appearance of a portion of a stem about five inches in diameter, though really a bundle of parallel roots, each 5 to $8 \mathrm{~mm}$. in diameter, the other shows its fascieular nature more evidently. The tissues are preserved in a red jasper, and dusty haematite considerably obscures the structures. "The cellular structure has been quite disintegrated. There- is a solid core of woody tissue traversed by innumerable medullary rays that run almost from the very centre to the cortex, traces of the latter being quite evident (see Plate xxi., figs. 11, 12). All trace of protoxylem seems to have been destroyed. There appears no sign whatever of annular rings, though the secondary wood is of considerable thickness, the average radius of the roots being $6-7 \mathrm{~mm}$. There is no trace of pith structure. The secondary wood starts abruptly upon an indefinite mass showing no cellular structure, but which we may interpret to be at least the position of the phloem, the entire phloem having been replaced by silica. An outstanding feature of the secondary xylem is the apparent uniformity of its cellular structure. If its elements are tracheids, which seems to be the case, they appear to be uniform in their size and structure from the position of the phloem to the cortex. From the longitudinal section all traces of bordered pits have been completely obliterated. To what group of plants these roots belong it would be difficult to say until further evidence is obtained as to the detailed structure of their protoxylem and other tissues." The slides are in the collection of the University of Sydney.

Mr. Chapman describes, in the appendix, the occurrence of Girvanella in the oolitic limestones of the Parish of Babbinboon.

The marine fossils of the Burindi Series so far obtained from the Currabubula, Somerton, Carroll and Babbinboon Districts comprise the following forms:-

\section{COELENTERATA.}

\section{Zaphrentis (Plerophyllum) culleni Eth. fil.}

Mem. Geol. Surv. N.S.W., Pal. No. 5, pt. 1, 1891, p. 13, t. 9, f. 1-7.

This form oceurs rather abundantly near the railway cutting four miles east of Currabubula. Collected by Benson.

\section{Zaphrentis sumphuens Eth. fil.}

Mem. Geol. Surv. N.S.W., Pal. No. 5, pt. 1, p. 16, t. 11, f. 4-6.

This form was described from the Somerton District; it also oceurs in the south-eastern portion of Babbinboon. Collected by Benson. 


\section{ZAPHRENTIS SP. INDET.}

This is a large form, the calyx of which is about an inch in diameter, but is stated by Dr. Smith (in a private communication) to be too poorly preserved to admit of specific determination. It occurs in the small mass of limestone north of the railway cutting four miles east of Currabubula.

\section{Lithostrotion SP.}

Mitchell has reported finding a specimen of this genus, as recognised by Sowerby, at Perimbungay, near the junction of the Peel and Namoi Rivers in $1831(9)$.

Amygdalophyllum etheridgei, gen. et sp. nov. (Plate xviii.; Text-fig. 10.)

The material for the investigation of this form consists of one specimen showing the external form, but not that of the interior of the calyx, and four other specimens from which have been obtained six transverse and two longitudinal sections.

The corallum (Plate xviii., fig. 1) is simple and turbinate, marked by slight growth ridges, and rapidly increasing in diameter from apex to the bell-like calyx. The length of the corallum must have been originally about sixty millimetres; its greatest diameter is forty-two. The external wall has been removed for the most part, exhibiting the ends of the septa, which follow the plan, normal to the Rugosa, of addition at four points. Where the coral has a diameter of about ten millimetres there are thirty-eight septa visible, but where the diameter is thirty-five millimetres the number of visible septa is increased to between ninety and a hundred. Transverse sections show that the outer wall was thin, and very slightly undulating, being apparently devoid of rugae and costae. The septa are in two cycles, the longer reaching to the columella, the shorter extending to the inner limit of the dissepimental zone. Septa of both eycles are stout, generally increas-

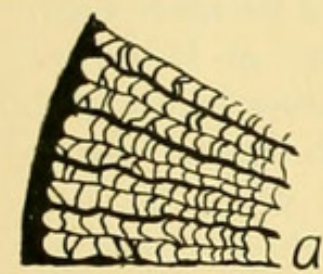

Diameter $20 \mathrm{~mm}$

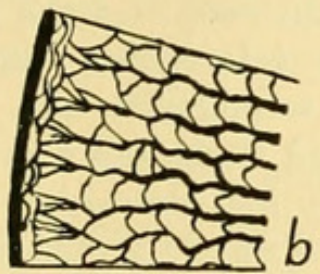

$35 \mathrm{~mm}$

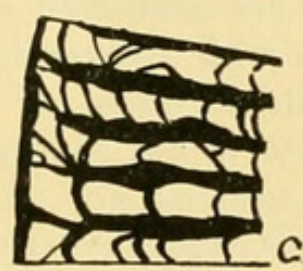

$55 \mathrm{~mm}$

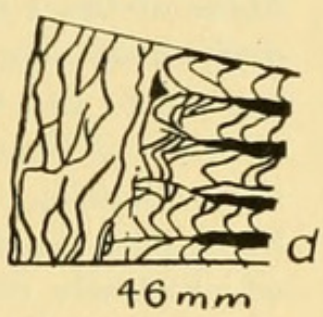

$46 \mathrm{~mm}$

Text-fig.10.-Section of portions of the corallum of Amygdalophyllum etheridgei, gen. et sp. nov., to show the relation of the septa to the wall. Babbinboon.

ingly so as they proceed further from the columella, this being especially marked within the dissepimental zone. Generally the longer septa are more thickened than those of the second cycle, but in some cases this distinction is not noticeable in the outer parts. The septa of both cycles nearer the apical portion of the corallum pass directly into the wall (Plate xviii., f. 3 ; also Text-fig. 10a), but later they become much thinner as they approach the wall, somewhat flexuous in some cases, and supported from the wall by a number of obliquely placed lamellae (Plate xviii., fig. 2, Text-fig. $10 b$ ). In the sections of greatest diameter the septa may not reach the wall at all, but near it branch out into the oblique supporting lamellae 
which in turn are joined to the wall (see Text-fig. 10c). Indeed, in some eases, the wall is replaced by a broad zone of vesicular tissue composed of long cells flattened parallel to the outer surface (see Text-fig. 10d). The septa spring from the inner side of this zone. In regard to the illustrations, it should be noted that the originals of Text-figures $10 a$ and $d$ are cut from the same corallum. The greatest number of septa observed in a transverse section was sixty of the longer cycle, and an equal number of intervening septa of the shorter cycle. No trace of a fossula is present. Some variation is seen in the manner of attachment of the longer septa to the columella. In some cases (Plate xviii., fig. 4) they pass directly into the columella and appear to radiate from its outer margin, though two or three of the septa occasionally coalesce before reaching the columella; in other cases (Plate xviii., fig. 2) they are crowded together, bent, and even broken as if they had been twisted and thrust against the columella. Intermeriate stages of partial twisting occur (e.g., Plate xviii., fig. 3), but this does not seem to be referable to the stage of growth.

The most remarkable feature of the coral is the nature of the columella which is a thick solid rod of roughly elliptical cross section, one end of the major axis being drawn out into a sharp point, directed probably towards the cardinal septum (Plate xviii., figs. 2, 4). As in the ease of Lithostrotion, this appears to be essentially an enlargement of the plate joining the cardinal and counter septa. This plate may be clearly seen in the centre of the columella (Plate xviii., figs. 4, 6) and in the larger transverse sections is about three millimetres long and a fifth of a millimetre in width. About it has been deposited a layer of lime carbonate $3 \mathrm{~mm}$. thick, so that the major and minor axes of the columella are as much as 9 and 5 or $6 \mathrm{~mm}$. respectively. This layer is made up of fibres radiating from the original plate within, and to a less extent from the extensions of this plate into the septa at either end (Plate xviii., fig. 6). The other septa also appear to be continued into the structure of the stereoplasm and to join the primitive plate. The connection is most clear in the eases where the septa are not twisted (Plate xviii., fig. 4), in which case the darker, rather flexuous fibres of the columella are continued into the centre of the septa. Between such dark lines connecting with the septa are intervening dark lines, as if corresponding to the distant septa of the secondary eycle. In other cases the relation of lines to septa is not so clear, and if the septa are much twisted about the columella, the connections are more or less destroyed (Plate xviii., fig. 6). Sometimes the dark lines cannot be separated from the general radiating structure. which closely resembles that of oolite. At other times this resemblance is rendered still more striking by the development of concentric layers in the thickening of the columella (Plate xviii., fig. 4).

The dissepimental zone extends about three quarters of the distance, more or less, from the wall to the columella. The vesicles are most elosely packed in that portion which is nearest to the columella and forms a half to a third of the width of the dissepimental zone. The outer and inner limits of this zone of closely packed vesicles may have the dissepiments so thickened as to form more or less continuous walls, the latter or thecal wall at, or just within, the eircle touching the ends of the shorter septa. Generally, however, there is little or no sign of these structures. The oblique but nearly longitudinal section (Plate xviii., fig. 5) shows that the dissepiments are ranged in a steeply descending series; the largest vesicles in the central portion of the dissepimental zone are about three millimetres in length, and one in width, though usually they are about half that size, and less than that in the region of closest packing. 
The tabulae are somewhat irregularly spaced, being frequently about a millimetre apart, and often eloser together. They have a general upward arehing, but this is not marked. Sometimes they are continuous across several septa, but at ther times are confined to one interseptal space. There is no apparent stereoplasmic thickening on the tabulae and very little if any on the dissepiments.

This form appears to be closely related to Konincloophyllum inopinatum Eth. fil., which occurs in the Carboniferous limestone of Lion Creek, Stanwell, near Rockhampton.* It differs from this form, however, in that the primary septa reach and unite with the columella, while those of Koninckophyllum do not do so, and that the septa of the second cycle are two-thirds or three-quarters of the length of the prinary septa, instead of being only one-half as in the ease of Koninckophyllum. In some respects also the form appears to be allied to Cyathaxonia, as pointed out in a private communication from Dr. Stanley Smith. Though the corallite is simple, its structure resembles that of such forms of Lithostrotion of much smaller diameter, as L. stanvellense Eth. fil., which Dr. Smith has recognised in the Burindi Beds at Hall's Creek, south of Bingara. ${ }^{* *}$ It is interesting to note that his remark that the stoutness of the columella, and the tendency of the septa to end in the area of dissepiments, and not quite reach the epitheca, features which are present in the form described here, are features which distinguish the Australian forms of Lithostrotion from the British types. On account of the shape of the transverse section of the columella, we have adopted for this genus the name Amygdalophyllum, suggested to us by Professor David, F.R.S. The species, the only one yet known, we dedicate to the late Robert Etheridge, Junr., in appreciation of his fifty years of work on the Geology and Palaeontology of Australia. This form was collected in the south-east of Babbinboon by Mrs. Scott and Benson. The type material will be placed in the collection of the Geological Survey.

\section{DIPHYPHYLLUM SP. INDET.}

Indefinite specimens provisionally referred to this genus were obtained by Cullen from the Parish of Moorowarra. These are recorded as numbers 4510 and 4515 in the collection of the Geological Survey. This is perhaps a Lithostrotion (cf. Smith, 1920, loc. eit.).

\section{TRYPLASMA ? SP. INDET.}

A very indefinite fragment doubtfully referred to this genus is found on specimen 4419 in the collection of the Geological Survey, and was obtained by Cullen in the Parish of Moorowarra.

\section{Michelinia tenuisepta (Phillips).}

Calamopora tenuisepta, Phillips, Illus. Geol. York., ii., 1836, p. 201, t. 2, f. 3. Michelinia tenuisepta, De Koninck, Anim. Foss. Terr. Carb. Belg., p. 31, t. c., t. 3; R. Etheridge, Junr., Mem. Geol. Surv. N.S.W., Pal. No. 5, pt. 1, 1891 p. 28 , t. 4 , f. 1 .

The form was found in New South Wales first at Carroll, and compared dubiously by $\mathrm{Mr}$. Etheridge to the above species. Later and more perfect specimens have confirmed the determination. Our specimen was collected by Mrs. Seott in the south-east of Babbinboon.

*R. Etheridge, Junr., Geol. Surv. Queensland, Bull. 12, 1900, pp.20-21, t.1, f.2; t.2, f.9, 10. According to a private communication from Dr. S. Smith, Etheridge's Koninckophyllum is certainly not Thompson's Koninckophyllum.

*S. Smith, On Aphropvllum hallense, gen. et sp. nov. and Lithostrotion from the Neighbourhood of Bingara. N.S.W. Proc. Roy. Soc. N.S. W., liv., 1920. 


\section{CRINOIDEA.}

\section{Cactocrinus ? BROWNei, sp. nov. (Plate xix., fig. 1.)}

The specimen is an external east, in a ferruginous mudstone or argillaceous limonite, of a part of a calyx showing the upper portion of the first columnal and the right and left massed basal plates, the anterior not being visible. In the radial eycle ean be seen the hexagonal anal plate, broad and symmetrical in form, with its superimposed inter-radial plates, of which three eycles are preserved. The plates generally are characterised by their regularity of form and hexaradiate ornamentation, the point of radiation being marked by a tubercle. No definite 1dea can be obtained as to the nature of the tegmen, nor as to the condition of the anal opening, nor yet of the brachia. The general form of the calyx is globose and somewhat depressed. The form is not comparable directly with any known form except perhaps Cactocrinus ectypus (Meek and Worthen), though differing widely from it in ornamentation. The classification of the Actinocrin:dae, so characteristic of the Lower Carboniferous formations, is based on the condition of the anal tube, and the conformation of the brachials, information as to which cannot be obtained from our specimen. It appears, however, from the shape of the radial and fused brachial plates to approach closely to Wachsmuth and Springer's Cactocrinus.

Dimensions: Height of calyx, $18.5 \mathrm{~mm}$; breadth of calyx, $26.0 \mathrm{~mm}$; height of anal plate, $4.0 \mathrm{~mm}$; breadth of anal plate, $4.0 \mathrm{~mm}$; height of right posterior radial plate, $4.5 \mathrm{~mm}$; breadth of right posterior radial plate, $3.7 \mathrm{~mm}$.

We name this in honour of our colleague, Mr. W. R. Browne, B.Sc. Our specimen was collected by Mr. W. Donaldson, south of the railway line, four miles east of Currabubula, and is now specimen No. F12,454 in the collection of the Geologieal Survey.

A fragment of a calyx with an ornamentation very similar to that shown on $C$. brownei which has been figured and described as Actinocrinus sp. indet. was found in the Star Beds near Rockhampton, Queensland.*

$$
\text { BRYOZOA. }
$$

Thamniscus SP. INDET.

King, Ann. Mag. Nat. Hist., (2), iii., 1849, p. 389.

In manuseripts left by the late $\mathrm{Mr}$. R. Etheridge, Junr., a form not determinable specifically was described as belonging to this genus. It was collected in the parish of Moorowarra, south of Somerton, by Cullen, and near Carroll by Porter.

\section{Fenestella spp. indet.}

Indeterminate specimens belonging probably to this genus, oceur four miles east of Currabubula. Collected by Benson.

\section{BRACHIOPODA.}

\section{Orthotetes (Schellwienella) crenistria (Phillips).}

Orthotetes crenistria, Dun, Rec. Geol. Sur. N.S.W., vii., 1902, p. 82, t. 23, f. 11. and Bibliography. 
Schellwienella crenistria, Thomas, The British Carboniferous Orthotetinae, Mem. Geol. Surv. Gt. Brit., Pal. I., Pt. ii., 1910, p. 92.

This readily recognised form was found by Benson at the railway eutting four miles east of Currabubula, and again in the south-east of Babbinboon. The largest specimen found, if perfect, would have had a breadth of $70 \mathrm{~mm}$. and length of $40 \mathrm{~mm}$.

According to De Koninck (30) this form is rather rare in the Lower Carboniferous but very abundant in the upper beds of the Carboniferous Limestone. Modern British workers, however, have divided $O$. crenistria into a number of varieties of which the most important form is termed Schellwienella crenistria and recognise the species sensu stricto extending from the base of the Carboniferous up to the zone $\mathrm{C}_{2},{ }^{*}$ while varieties, e.g., var. senitis, extend up to the zone $\mathrm{D}_{2}$. It has even been found in the Millstone Grit of the Welsh Border (31, p. 251) (? a facies of $\mathrm{D}_{2}$ ). It is apposite here to eite a remark of Davidson (31, p. 290 ) apropos of Streptorhynchus cnenistria var. senilis.- "Some palaeontologists seem disposed to erect this important variety into a distinct species, and it cannot be denied that in some localities, particularly in Australia, it alone occurs."

\section{Chonetes aspinosa Dun.}

Dun, Rec Geol Surv. N.S.W., vii., 1902, p. 69, t. 19, f. 1-3, t. 20, f. 1-5.

This species was proposed by Dun to receive forms previously classed as Chonetes ef. comoides, Daviesiella ef. comoides, or Productus ef. giganteus. Probably should be here included the form referred to the last designation which was obtained by Mr. Pittman from Somerton. Forms compared, but not identified with, any one of the three above-mentioned species, are cited as occurring between the zones $\mathrm{C}_{1}$ and $\mathrm{D}_{1}$ in the Carboniferous rocks of Great Britain.

Chonetes ef. hardrensis (Phillips).

For Bibliography see De Koninek, Pal. Foss. N.S.W. Mem. Geol. Surv. N.S.W., Pal. No. 6, 1898, pp. 66-8.

Two small specimens, not well preserved, which may be referred to this species were obtained by Benson from the railway cutting four miles east of Currabubula. The dimensions of these were length, $5 \mathrm{~mm}$., breadth, $8 \mathrm{~mm}$.

This form oceurs both in Devonian and Carboniferous beds of this State as elsewhere, though De Koninck (op . cit.) urges that specific differences may be found between the types belonging to the two Periods. This, however, does not appear to be the view of modern British workers who record it as ranging from the base of the Carhoniferous System up to the zone $\mathrm{C}_{2}$.

Productus hemisphaericus (Sowerby). (Plate xix., fig. 8.)

Jas. Sowerby, Min. Conch., 1822, t. 328; Productus giganteus var. hemisphaericus, Davidson, Brit. Carb. Brach., 1858, p. 144, t. 40, f. 4-9.

Of this form there is only the cast of a pedicle valve available for study. It agrees so closely with Davidson's diagnosis and figure that no individual description is necessary here. Its dimensions are: Length, $28 \mathrm{~mm}$; breadth, 35 $\mathrm{mm}$.; length of hinge line, $30 \mathrm{~mm}$.

This form was obtained by Benson from the south-east of Babbinboon, and is in the collection of the University of Sydney. It was also recorded by Dun as

*For the explanation of this notation, see p.368. 
the provisional determination of a shell from Rawdon Vale. In Great Britain and Ireland this form ranges between the zones $\mathrm{S}_{1}$ and $\mathrm{D}_{2}$.

\section{Productus ef. Longispinus (Sowerby).}

Jas. Sowerby, Min. Conch., i., 1814, p. 154, t. 68, f. 1; Davidson, Brit. Carb. Brach., 1858, p. 154, t. 35, f. 5-17.

This small form is represented by a single pedicle valve obtained by Benson from four miles east of Currabubula. It is a depauperate form, $7 \mathrm{~mm}$. long and $6 \mathrm{~mm}$. broad, but otherwise conforms to Davidson's diagnosis. The species was provisionally recorded as being found at Greenhills, near Paterson, in 1898. This form is "present in almost any Carboniferous district where brachiopoda have been found." In Great Britain it ranges from the zone $S_{2}$ to the zone $\mathrm{D}_{2}$.

Productus muricatus (Phillips). (Plate xxiii., figs. 1-3.)

Phillips, Illus. Geol. York., 1836, t. viii., f. 3; Davidson, Brit. Carb. Brach., 1858, p. 153 , t. 32 , f. $10-14$.

This shell is sub-circular in outline, the hinge line somewhat shorter than the greatest width of the shell. The pedicle valve is very evenly rounded so as to give an almost semicircular profile. It is ornamented by numerous rounded ribs with a small amount of reticulation near the beak. This is large and incurved. Except for the absence of spines (and our specimens are only casts), this form agrees closely with Davidson's diagnosis.

Dimensions of three forms:

$\begin{array}{lllllrrr} & & & & a & b & c \\ \text { Breadth in millimetres.. } \ldots & \ldots & \ldots & \ldots & 18 & 18 & 18 \\ \text { Length from beak to margin } & \ldots & \ldots & \ldots & 15 & 18 & 15 \\ \text { Convexity . . . . . . . . . . . } & \ldots & \ldots & \ldots & 9 & 7 & 9\end{array}$

This form is remarkably abundant at the south-eastern portion of Babbinboon, and was also collected by Pittman from the "Whale's Egg," .five miles south of Somerton, in 1897, being represented by specimens 1574,1575 , and 1578 in the collection of the Geological Survey.

Davidson (31) states that it occurs in the Nillstone Grit, Upper and Lower Limestone Series of Scotland. In England and Ireland it oceurs in the zone of $\mathrm{D}_{1}$.

\section{Productus pustulosus (Phillips).}

Phillips, Ilius. Geol. York., ii., 1836, p. 216, t. 7, f. 1-5; Dun, Rec. Geol. Sur. N.S.W., vii.. 1902 , p. 72 , t. 23, f. $1,2,3,4$, and Bibliography.

This form was determined provisionally for this district on specimens No. 4579 and 4610 in the collection of the Geological Survey, obtained by Cullen from two miles west of Mt. Uriari. These have not been re-examined by us.

This form is present in the Lower Limestone Series of Scotland (31), and ranges in England and Ireland from zone $Z_{2}$ to $D_{2}$.

Productus semirfticulatus (Martin). (Plate xix., figs. 2-7: Text-fig. 11.)

Dun, Rec. Geol. Surv. N.S.W., vii., 1902, p. 79, t. 23, f. 4-9.

A number of examples of this very variable species are figured to show the range of characters Figures 2 and 3, Plate xix. illustrate a form, which we will 
term $(a)$, in which the radial ridges are very marked and extend only about a quarter of the way from the beak to the margin. Figures 4 and 5 illustrate $(b)$, a form that is rather erushed so that the curved outline is fractured. The radial and transverse ridging is not so deeply marked, but the sinus is more noticeable. It has a heavier, coarser ornamentation than the majority of the examples of this species from the Burindi Beds. The shell $(c)$ in Figures 6 and 7 , is smaller than the other forms, and the outline of the pedicle valve seen in profile is more acutely elliptical than usual. The well-marked concentric ridging covers more than a third of the surface of the valves. The radial ridges, however, are not s? continuous as usual. The fourth specimen, Text-fig. 10, is distinguished from the other forms by its greater breadth relative to the length, by the presence of prominent ears, by the even convexity of the pedicle valve and by the fact that the reticulate area covers almost half the shell. The dimensions of these four shells are as follow :-

$\begin{array}{lllllllll} & & & & a & b & c & d \\ \text { Breadth in millimetres } & \ldots & \ldots & \ldots & \ldots & 30 & 36 & 17 & 24 \\ \text { Length of hinge line } \ldots & \ldots & \ldots & \ldots & 27 & 34 & 15 & 23 \\ \text { Distance from beak to margin } & \ldots & \ldots & 23 & - & - & 17 \\ \text { Convexity of pedicle valve } \ldots & \ldots & \ldots & 10 & - & 11 & 9\end{array}$

This form was collected by Porter near Carroll; by Mrs. Scott and Benson in the south-east of Babbinboon.

According to Davidson (31), it extends through the Calciferous Sandstone of Scotland into the Upper Limestone, and is also found in the Millstone Grit of

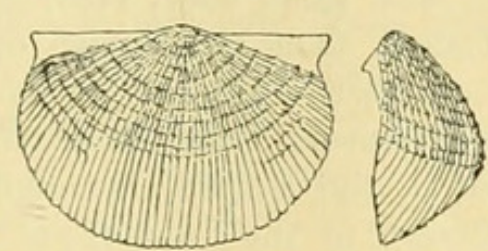

Text-fig.11.-Productus semireticulatus. Babbinboon.

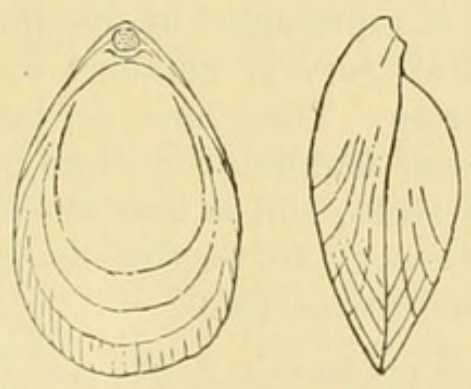

Text-fig.12.-Dielasma sacculum var. amygdala (Dana). Somer-

the Welsh Border. Frech (32) states that it occurs in the lower portion of the Viséan in France and Belgium, and in Russia, and in America it is found throughout the Upper and Lower Carboniferous Formations (33).

\section{Orthis (Schizophoria) Resupinata (Martir). (Plate xix., figs. 10, 11.)}

Anomites resupinata, Martin, Petrif. Derb., 180!, p. 12, t. 49, f. 13-14; Schizophoria nesupinata, Dun, Rec. Geol. Surv. N.S.W., vii., 1902, p. 78, t. 21, f. 3-9 and Bibliography there cited.

This widely distributed form has been obtained from most of the known fossiliferous localities in the Somerton District. and was also found by Benson four miles east of Currabubula. None of the forms are well preserved, but those here figured conform in all essentials to the diagnosis of the species. In both, the margin forms a smooth eurve, but the sinus is rather marked in one, while in the 
other the beak is more prominent and separated from the ears by a marked flexure. Its margin also is elliptical rather than quadrate. The length of the form from beak to margin is from 30 to 35 millimetres; the breadth is 45 .

According to De Koninck (30) who first recorded this form in New South Wales, it ranges throughout the whole of the Carboniferous System. In Scotland it is found from the Upper Limestone Series to the base of the Calciferous Sandstone (31). In England and Ireland the range is from the zone $Z_{2}$ to that of $D_{1}$.

Orthis (Rhipidomella) australis (MeCoy). (Plate xix., fig. 9.). Orthis australis, MeCoy, Ann. Mag. Nat. Hist., xx., 1849, p. 234, t. 13, f. 4-4A; Rhipidomella australis, Dun, Ree. Geol. Sur. N.S.W., vii., 1902, p. 81, t. 21, f. 10-11, and Bibliography there eited.

The specimens obtained by Mrs. Scott from the south-east of Babbinboon, are all such as show the external form only, and therefore difficult to assign to either Orthis michelini or Orthis australis. The known abundance of the latter, and improbability of the occurrence of the former may be taken as deciding the nomenclature of these specimens. The size is normal or rather small. Breadth, $21 \mathrm{~mm}$., length, 19, and depth or thickness, $5 \mathrm{~mm}$. Less well developed specimens were collected by Benson four miles east of Currabubula, and by Cullen from Somerton.

Rhynchonella PLeurodon (Phillips).

Terebratula pleurodon, Phillips, Illus. Geol. York, ii., 1836, p. 222, t. 12, f. 25, 30 ; Rhynchonella (Pugnax) pleurodon, Dun, Rec. Geol. Surv. N.S.W., vii., 1902, p. 18, t. 23, f. 10, 11 and Bibliography.

This form is represented by specimens Nos. 4385, 4434, 4435, in the collection of the Geological Survey, obtained by Cullen from the Parish of Moorowarra, south of Somerton. These have not been eritically examined by us. The species, however, has been determined eritically in specimens from Clarencetown oceurring in the Burindi rocks, and is also abundant in the Upper Devonian rocks of Mt. Lambie and Yalwal. In Scotland it is known in the Calciferous Sandstone and Lower Limestone Series (31) .

Rhynchonella (?) sp. indet. (Plate xix., fig. 13.)

A single specimen of an indeterminate form which may be related to this genus has been obtained by Mrs. Seott from the south-east of Babbinboon. Its length and breadtt are about 8 millimetres, and it is ornamented by fourteer strongly-marked radiating ribs. The evidence is insufficient to justify our assigning this to any known species.

Dielasma sacculum (Martin) var. hastata (Sowerby). (Plate xix., fig. 12.)

Terebratula hastata, J. Sowerby, Min. Conch., 1824, t. 446, f. 2, 3; Dielasma sacculum var. hastata, Dun., Rec. Geol. Surv. N.S.W., vii., 1902, p. 83, t. 21, f. 13, and Bibliography eited.

Numerous examples of this form have been obtained by Mrs. Scott from the south-east of Babbinboon. The dimensions show considerable variation; the foilowing measurements being representative:-

\begin{tabular}{|c|c|c|c|}
\hline & $a$ & $b$ & $c$ \\
\hline Length (beak to margin) . . . . & 20 & 27 & 18 \\
\hline 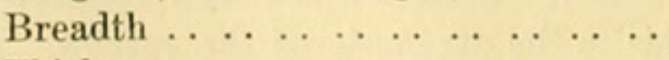 & 16 & 16 & 14 \\
\hline 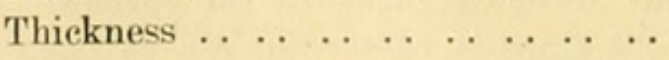 & 8 & - & 8 \\
\hline
\end{tabular}


The last is a small form obtained by Benson from the railway-eutting, four miles east of Currabubula.

This form ranges from the base of the Carboniferous to the Upper Limestone Series in Scotland (31), and is most abundant in the Upper Carboniferous Limestone of Belgium, though extending to the lower portion (30). In England it ranges from $\mathrm{C}_{1}$ to $\mathrm{D}_{1}$. It also is found in the Permo-Carboniferous beds of this State.

\section{Dielasma sacculum (Martin) var. amygdala (Dana). (Text-fig. 12.)}

Terebratula amygdala, Dana, Amer. Jour. of Seience (4), ii., p. 152; also in Report Wilke's U.S. Explor. Exped., Geol., 1849, p. 682, t. 1, f. $2 a, b$.

This variety differs from $D$. hastata in its very elongated form. The figured specimen, now in the collection of the University of Sydney, was obtained by Mrs. Scott from the south-east of Babbinboon, and has the following dimensions:Length, $27 \mathrm{~mm}$., breadth, $17 \mathrm{~mm}$., thickness, $12 \mathrm{~mm}$.

This form also has been obtained from the Burindi rocks at Somerton, represented by specimen 1511 in the collection of the Geological Survey. This was figured (Mem. Geol. Surv. N.S.W., iv., t. 33, f. 8) as D. hastata. At present its Museum label is D. hastata amygdala (Dana).

The form was first described from the Upper Marine Permo-Carboniferous Beds which are probably Permian (4).

Spirifera bisulcata (Sowerby.) (Plate xxi., fig. 1.)

J. Sowerby, Min. Conch., iii., 1820, p. 17, t. 23, f. 2, 3; Davidson, Brit. Carb. Brach., 1856 , p. 31 , t. 4, f. 1 (?) ; t. 5 , f. 1 ; t. 6 , f. $1-19$; t. 7 , f. 4 ; L. G. de Koninck, Foss. Pal. N. Galles, 1877, (English Translation, 1898, p. $192-3$, t. 14 , f. 5.)

This form is smaller than S. striata, and is characterised by the deep suleus on either side of the mesial fold. The form figured here closely resembles Davidson's figure ( $O p$. cit., t. 6, f. 8) of Sowerby's type specimen. There are thirteen ribs on either side of the sinus, in which are three obtusely rounded ribs. Length, about $25 \mathrm{~mm}$; breadth $26 \mathrm{~mm}$. Locality,-S.E. Babbinboon. Collected by Mrs. Seott. This form was also obtained by Mr. Pittman, 5 miles S.E. of Somerton. In the railway-eutting, four miles east of Currabubula, Benson has collected small and rather more transverse specimens, with a greater number of ribs, resembling Davidson's t. 6, f. 19. This form has the sulci on either side of the mesial fold more strongly marked, and small ribs intercalated near the margir. separate the three low, broad ribs on this fold, and these are slightly sinuous. Length, $15 \mathrm{~mm}$; breadth, $32 \mathrm{~mm}$. De Koninck points out that this species is very abundant in the upper beds of the Carboniferous Limestone at Visé in Belgium and in Great Britain, but oceurs also in the Lower Limestone Series and Calciferous Sandstones of Scotland (31). In England and Ireland the range is from the zone $\mathrm{C}_{2}$ to $\mathrm{D}_{2}$, and also extends into the Millstone Grit (31, p. 251).

SPIRIFERA DAVIDIS Dun.

Ree. Geol. Surv. N.S.W., vii., 1902, p. 323, t. 60, 1. 1, $a-f$.

This species was obtained by Cullen from the Parish of Moorowarra, south of Somerton, and also near Carroll. (See specimens 4360, 4374 and 4390 of the collection of the Geological Survey). Nothing need here be added to the deseription previously given. 


\section{Spirifera duplicicostata (Phillips). (Plate xxiii., fig. 4.)}

Phillips, Illus. Geol. Yorks., ii., 1836, p. 218, t. 10, f. 1; Davidson, Brit. Carb. Brach., pp. 24,221 , t. 3 , f. $7-10$; t. 4 , f. $3,5-11,15-16$ ?; t. 5 , f. 35 , 37; t. 52 , f. 6 .

The pedicle valve is very similar to Davidson's t. 4 , f. $15-16$, though it is too imperfect to permit the observation of the marked inflection of the marginal region. There is, however, a broad suleus with about thirteen fine ribs therein, and about thirty-five striations on either side. While originally considering the forms illustrated in these figures as $S$. humerosa, Davidson later (p. 221) states that he is inclined to refer these forms to $S$. duplicicostata. This course is therefore followed here. The specimen is No. F.1652 of the Geological Survey collection, and was obtained near the "Whale's Egg," five miles south-east of Somerton by Mr. Pittman. This form oceurs in the zone of $\mathrm{D}_{1}$ in England.

SPIrIfera ef. Mosquensis (Fischer). (Plate xx., figs. 4, 5, 6.)

Choristites mosquensis, Fischer de Waldheim, Programme sur les Choristıte, p. 8, No. 1, 1837, and Oryctogr. du gouv. de Moscow, 1831, p. 140, t. xxii., f. 3 ; t. xxiv., f. 1-4; Spirifera mosquensis, De Vernueil and Keyserling, Russie et Oural, Vol. II., p. 161, t. v., f. 2; Davidson, Brit. Carb. Brach., p. $22-3$, t. iv., f. 13,14 ; t. xiii., f. 16 .

This form differs from S. striata in the greater length of the shell. In our form there are about sixty ribs, which are very much broader on the sinus than towards the ears, about ten ribs oceurring on the sinus and mesial fold. There is very little sign of concentric ornamentation. The length of hinge line is rather less than the greatest width of the shell, and the area on the pedicle valve has almost parallel sides and is about $3 \mathrm{~mm}$. wide, and marked with faint vertical striation.

Dimensions: Breadth, $37 \mathrm{~mm}$. (length of hinge $33 \mathrm{~mm}$.); length of pedicle valve, $35 \mathrm{~mm}$; thickness of shell, $23 \mathrm{~mm}$.

Our specimen was obtained by Mrs. Scott from the shelly ridge in the S.E. of Babbinboon, and is in the collection of the University of Sydney. Other specimens from Carroll Gap have been received by the Australian Museum from Mr. D. A. Porter; and these forms approach more closely to Davidson's illustration of $S$. mosquensis than does our specimen in the more marked character of the median fold.

According to Frech (32) this species is a characteristic fossil of the lower portion of the Upper Carboniferous. A variety of it oceurs in the zone $\mathrm{D}_{2}$ in England.

SPIRIFfipa Pinguis (Sowerby). (Plate xxi., figs. 9, 10.)

Sowerby, Min. Conch., iii., 1820, p. 125, t. 271; Davidson, Brit. Carb. Braci., p. 50 , t. 10, f. 1-12; S. pinguis var. rotundatus, L. G. de Koninck, Foss. Pal. N. Galles Sud., 1877, English Translation 1898, p. 185, t. 14, f. 2, 2a; S. pinguis, Dun, Rec. Geol. Surv. N.S.W., vii., 1902, p. 84, t. xxii., f. 1, 2,5 .

The specimens obtained from Mrs. Scott are typical examples of the species. The larger has a length of $43 \mathrm{~mm}$. and a breadth of $40 \mathrm{~mm}$., there being eight

*Davidson states:- "Prof. L. G. de Koninck assures me that the true Russian Spirifera mosquensis has not been found in Great Britain, and that what has been re. ferred to it are merely variations in shape of Spirifera striata, and I feel inclined to adopt the Professor's view." Brit. Carb. Brach., Suppl., 1880, p.315. 
ridges on either side of the sinus, which, however, are unusually coarse in character. The other form is slightly less elongated proportionately. The length is 29 $\mathrm{mm}$. and breadth $32 \mathrm{~mm}$. Locality: Shelly Ridge, S.E. of Babbinboon. De Koninck states that this is one of the most abundant forms in the Middle Carboniferous Limestone. In Great Britain this form ranges throughout the zones $\mathrm{C}_{1}-\mathrm{C}_{3}$.

Spirifera pinguis var. elongata, var. nov. (Plate xx., fig. 11; Text-fig. 13.)

This form differs from $S$. pinguis in the greater elongation of the shell. Two specimens have come under our notice. That illustrated in Plate xx., fig. 11, is a single pedicle valve with much the same form as $S$. reedi (Davidson), though twice the size. It has an elongate-oval outline; the hinge line is shorter than the greatest width of the shell, and the cardinal angles are rounded. The beak is of moderate size and strongly incurved over a triangular delthyrium. The shell is smoothly convex with a broad medial sinus extending into a tongue-like projection of the margin. On either side are about ten low, rounded ribs; concentric lamellar growth lines cross the sinus near the margin. The other, shown in Text-figure 13, is even more markedly elongate, and somewhat distorted in outline. The shell has been largely removed but sufficient remains to show that the ornamentation was much finer than in the first specimen, about twenty ribs oceurring on one side of the mesial fold on the brachial valve, and the ornamentation of the pedicle valve appears to have been as fine. A few concentric growth lines are present on each valve. The dimensions are:-

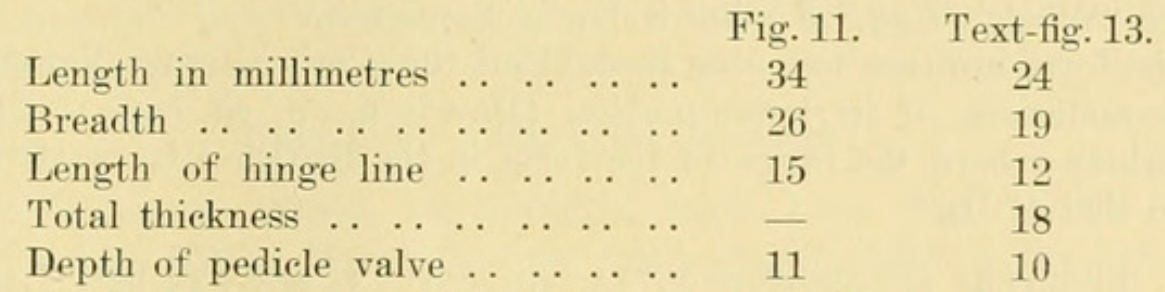

The first of these forms was obtained by Benson in the south-east of Babbinboon, and is in the collection of the University of Sydney. The second (Specimen No. F 4360 of the Geological Survey Museum, N.S.W.) was obtained by Cullen from Reserve 121, Parish of Moorowarra.
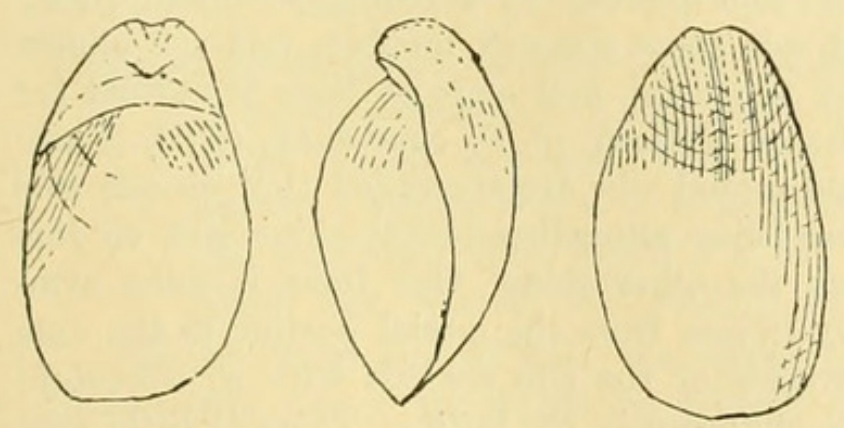

Text-fig.13.- Spirifera pinguis var. elongata, var. nov. Mioorowarra.
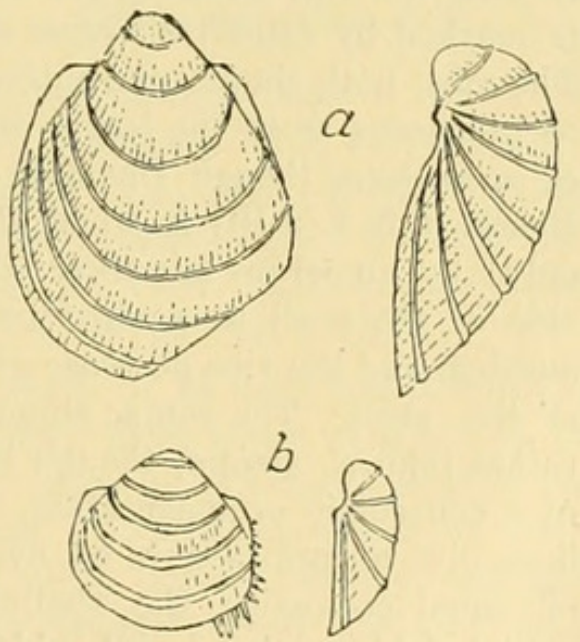

Text-fig.14.-Posidoniella? spp. indet. Babbinboon. 


\section{Spirifera striata (Sowerby). (Plate xx., figs. 1-3.)}

Sowerby, Min Conch., 1820, t. 270; Davidson, Brit. Carb. Brach., 1852, p. 19, t. 2, f. 12,14 ; t. 3 , f. $2-6$; Ibid. Carb. Suppl., 1880 , p. 274, t. 31, f. 1, 2, 3, 4; Dun, Rec. Geol. Surv., N.S.W., vii., Pt. 2, 1902, p. 8?-4, t. xxii., f. 6-9, and Bibliography.

As may be seen from Davidson's figures, there is considerable variety in the forms grouped under this species. Three specimens are illustrated here. That represented by Plate xx., fig. 1, closely resembles Davidson's illustration (op. cit. supra, t. 3 , f. 4 ), though the ribs are not so numerous. It is the most alate of the three. There are about fifty radial ridges crossed by faint concentric lines. The sinus of the pedicle valve is somewhat deeply impressed near the margin, which is here flexed rather sharply and projected like a tongue in the dorsal direction. The beak is not quite centrally placed in one form. Its dimensions are (restored): Breadth, $55 \mathrm{~mm}$.; length, $23 \mathrm{~mm}$. The other forms are less broad. That shown in Plate xx., fig. 3 , has forty strongly-marked ribs, on which slight beading gives the only traces of concentric ornamentation. The (restored) breadth is $36 \mathrm{~mm}$., the length 25, and thickness $14 \mathrm{~mm}$. That shown in Plate xx., fig. 2 has less accentuated ribbing with searcely any other ornamentation. There are about fifty ribs which are much narrower and more closely spaced towards the ears than in the median portion of the shell. Breadth (restored), $56 \mathrm{~mm}$; length, $30 \mathrm{~mm}$; thickness, $18 \mathrm{~mm}$. These three forms were collected by Mrs. Scott from the south-east of Babbinboon. They were also ubtained by Mr. Pittman in 1897 from the "Whale's Egg," 5 miles S.E. of Somerton.

This form appears to oceur throughout the Carboniferous limestone, and is most characteristic of its lower portion (Davidson, op. cit. sup. p. 21). The recent workers record the range of the form in the British Isles as from the zone of $\mathrm{C}_{1}$ to that of $\mathrm{D}_{1}$.

\section{Spirifera Striato-convoluta, sp. nov. (Plate xx., figs. $7,8$. )}

This form is intermediate in character between S. striata (Sowerby) and $S$. convoluta (Phillips). It is broader in proportion to the length than S. striata but not so broad as convoluta. The hinge line resembles that of convoluta in extending the full widith of the shell. The area also is narrow, with parallel sides, is marked by faint transverse striation, and pierced by a triangular delthyrium. The ribs, both simple and interealated, are about sixty in number, and are almost as numerous as in the larger forms of S. striata, and more so than is normal for $S$. convoluta, though Davidson illustrates a form of $S$. convoluta (Brit. Carb. Brach., t. 5, f. 9-10) in which the broad mesial ribs are succeeded (but on one side only) by numerous narrower ribs, there being altogether twenty-seven ribs on this side of the shell as against twenty on the other side. Our form is more symmetrical and the ribs decrease gradually in size from the mesial portion to the ears of the shell. The rather sinuous character of the ribs accords with $S$. convoluta rather than S. striata, though it is not unknown in the latter. There is little sign of a concentric ornamentation, for the form is partly decorticated, but the growth lines give an appearance of overlapping lamellae. The valves are approximately of equal convexity the shallow sinus on the pedicle valve corresponding to a mesial fold on the dorsal which becomes more elevated near the margin, and is bent backwards into a tongue-like projection. No internal structures are visible. Dimensions: Length, $25 \mathrm{~mm}$; breadth, $49 \mathrm{~mm}$.; thickness, $9 \mathrm{~mm}$. Collected by 
Mrs. Scott from the Shelly Ridge in the S.E. of Babbinboon. The type-specimen is No. F 12461 in the Museum of the Geological Survey.

\section{SPIRIFERINA INSCULPTA (Phillips).}

J. Phillips, Geol. Yorkshire, ii., 1836, p. 216, t. 9, f. 2-3; Davidson, Brit. Carb. Brach., p. 42, t. 7, f. 48-55; De Koninek, Foss. Pal. N. Galles Sud, 1877, English Translation, p. 197.

A portion of the pedicle valve of a specimen of this form, corresponding, as far as could be seen, to the diagnoses of Davidson and De Koninck, was found by Benson four miles east of Currabubula. It is a pedicle valve, moderately convex, ornamented by five large bold angular ribs, separated by deep narrow grooves. Length of valve, $8 \mathrm{~mm}$; ; breadth, $11 \mathrm{~mm}$; thickness, $25 \mathrm{~mm}$. De Koninck states that this form belongs prineipally to the upper beds of the Carboniferous limestone $(30)$. It is recorded from the Upper Limestone Series only in Scotland (31). In England it ranges from the zone of $\mathrm{C}_{1}$ to $\mathrm{D}_{2}$.

\section{Syringothyris EXSUPERANS (De Koninck).}

Spirifera exsuperans, L. G. De Koninek, Foss. Pal. N. Galles Sud, 1877, English Trans., 1898, p. 195, t. 15, f. 1; Syringothyris exsuperans, A. H. Foord, Geol. Mag., 1890, p. 149, 153; R. Etheridge fil., Rec. Geol. Surv. N.S.W., vi., Pt. 2, 1897, pp. 43-49.

An example of this form has been recorded from "a shelly ridge twenty miles west of Tamworth." possibly that we have examined in the south-east of Babbinboon, where a distinctive fragment of this form was obtained by Mrs. Scott.

\section{RETZia ef. ulstrix (De Koninck).}

Terebratula (Crispata) ulstrix, De Koninck, Anim. Foss. Belg., p. 292, t. 19, f. 5; Retzia ulstrix, Davidson, Brit. Carb. Brach., 1858, p. 88, 218, t. 18, f. 14,15 ; t. 54 , f. 45.

A specimen referred provisionally to this form has been recorded from the parish of Bective at a spot to the south-east of Mt. Uriari. It has not been examined by us. This specimen is in the collection of the Geological Survey.

\section{Actinoconchus planosulcatus (Phillips). (Plate xxi., figs. 3,6.)}

Spirifera planosulcata, Phillips, Geol. Yorkshire, ii., 1836, p. 220, t. 10, f. 12; Athyris planosulcatus, Davidson, Brit. Carb. Brach., 1859, p. 80, t. 16, f. 2-13 15; De Koninck, Foss. Pal. N. Galles Sud., 1877, English Translation, 1898, p. 172, t. 9, f. 6 ; Actinoconchus planosulcatus, R. Etheridge, fil., Rec. Geol. Sur. N.S.W., v., Pt. 4, 1898, p. 177, t. 19, f. 18; Duñ, Ree. Geol. Sur. N.S.W., vii., 1902 , p. 87 , t. 21 , f. 17 ; t. 22, f. 12-14.

Of the forms figured here, the larger has a length of $24 \mathrm{~mm}$. and breadth of $36 \mathrm{~mm}$., the size of the single valve being thus nearly three times as great as the Australian form described by De Koninck. The other is somewhat smaller and less oblong-ovate. Length, $23 \mathrm{~mm}$; breadth, $27 \mathrm{~mm}$. This shows numercus traces of the ornamental fringes extending from the lamella, but the shell is smoothly convex, whereas the other form shows the characteristic broad shallow sinus. Collected by Mrs. Seott from Shelly Ridge, S.E. of Babbinboon, and by Cullen from Parish of Moorowarra.

De Koninck points out that this form occurs mostly in the Upper portion of the Carboniferous (Limestone?) especially at Visé. It occurs in the Upper and 
Lower Limestone Series in Scotland, but not in the Caleiferous Sandstene (31). In England and Irelond it ranges between the zones $\mathrm{S}_{1}$ and $\mathrm{D}_{1}$.

Semintla subtilita (Hall). (Plate xxi., figs. 2, 4, 5.)

Terebratula subtilita, Hall (In Stransburg), Explanation of the Valley of the Salt Lake of Utah, 1852, p. 409, t. 2, f. $1 a, b, 2 a, b, c$; Davidson, Brit. Carb. Brach.. p. 18, t. 1, f. 21, 22; Seminula subtilita, Hall aid Clarke, Pal. New York, viii., pp. 93-98, t. xlvii., f. 17-31.

This form was the first example of this widespiead genus to be recognised in this State, but it has since been recognised in the beds at Gosforth, which are probably transitional between the Burindi and Lower Marine Permo-Carboniferous Beds (4). The species is protean, and "one feels at first disinclined to include under the same specific designation the broadly ficiform, the narrow elongate, the sinuate, non-sinuate and tri-lobed forms, which are customarily thus referred, but the very abundant material shows the impossibility of separating them." (Hall and Clarke, op. cit., p. 95). Our form is a very neat shell. The margin is smooth, non-sinuate, and the test is ornamented by fine radial striae and broader concentric bands with a few irregular growth lines. Its length is $18 \mathrm{~mm}$; breadth, $25 \mathrm{~mm}$.; hinge line, $19 \mathrm{~mm}$; total thickness about $16 \mathrm{~mm}$. It was obtained by Mrs. Scott in the shelly ridge in the south-east of the parish of Babbinboon, and now is in the collection of the University of Sydney.

This form is widely developed in the Upper Carboniferous beds in the United States, but is found rarely in the St. Louis Limestone belonging to the Upper portion of the Mississippian System, the American equivalent of the Viséan Formation (33). In Belgium, however, it descends to the Tournaisian, according to De Koninck, as eited by Davidson (31, p. 219).

\section{PELECYPODA.}

\section{Sanguinolites triradiatus, sp. nov. (Plate xxiii., fig. 8.)}

Sanguinolites, MeCoy, Synop. Carb. Limestone Foss., Ireland, 1844, p. 47; Brit. Pal. Foss., Fase., ii., 1852, p. 276.

The shell is very elongate, the beak anterior and the lower posterior margin projects beyond the hinge line. It is characterised by the presence of three obtusely-rounded carinae, extending from the umbo to the posterior margin. It is also marked by numerous delicate concentric growth lines. It differs from $S$. tricostata (De Koninck)*, which is the most nearly allied form, in that our form is much narrower and the earination is less pronounced than in the Belgian form (which is found in the Viséan Series). The dimensions of $S$. triradiata are: Height, $10 \mathrm{~mm}$; length, $28 \mathrm{~mm}$; thickness, $25 \mathrm{~mm}$. The species is based upon Specimen F. 4584 of the collection of the Geological Survey, obtained by Cullen from the parish of Moorowarra, south of Somerton.

\section{Sanguinolites Sp. indet. (Plate xxiii., fig. 11 )}

This form does not appear very closely similar to any of the forms we have seen figured, but is not sufficiently well preserved for specific description. It has a carina forming a low rounded ridge except near the margin of the shell, and another running a short distance below it, commeneing as an angular ridge near the umbo, but fading out into the general eurve of lower posterior margin.

*Faune Cale. Carb. Belg., v., 1885, p.84, t.15, f.15. 
There is a faint sign of concentric ornamentation. The superior extent of the shell is slightly saddle-shaped. The dimensions of the shell are: Lengtn, $35 \mathrm{~mm}$.; height, $15 \mathrm{~mm}$.; thickness, $7 \mathrm{~mm}$.

This form is retresented by Specimen No. 4642 in the collection of the Geological Survey, and was obtained by Cullen from the parish of Moorowarra.

EDMONDIA SP. INDET.

This form is represented by Specimen No. 4363 in the collection of the Geological Survey, obtained by Cullen from the parish of Moorowarra.*

Ctenodonta sp. INDET.

A form provisionally referred to this species was obtained by Mr. Pittman from Carroll.*

Núdlana SP. iNdet.

This form is represented by Specimen No. 4689 in the collection of the Geological Survey. Collected by Cullen from Mt. Uriari.

\section{Parallelodon Carnei, sp. nov. (Plate xxi., fig. 7.)}

Parallelodon, Meek and Worthen, Proc. Chicago Acad., i., 1866, p. 17.

This is represented by the cast of a single left valve covered with a little of the original shelly material. It is nine $\mathrm{mm}$. in height. The hinge ine is seven $\mathrm{mm}$. long and shows no sign of teeth. The umbo is three mm. from the anterior end, and from it radiate many delicately marked striae erossed by a few concentric folds. This form resembles $P$. argutus (Phillips) of the European Carbonferous, but is more delicately ornamented. It is named in honour of $\mathrm{Mr}$. J. E. Carne, the late Government Geologist. It was collected by Mrs. Scott from the south-eastern portion of Babbinboon.

Pteronites (?) TANifteroides Eth. fil.

R. Etheridge Iunr. Rec. Geol. Surv. N.S.IV., viii., Pt. 3, 1907, p. 193, t. 37, f. $9-10$; t. 38 , f. 10.

Obtained from the west of Mt. Uriari.

\section{Pteronites sub-Pittmani (?) Eth. fil.}

R. Etheridge, Jun., Rec. Geol. Sur. N.S.W., iv., Pt. 1, 1894, p. 29, t. 6; ibid., viii,, Pt. 3,1907, p. 194 , t. 38 , f. 3.

In the original specimen of this species the umbo was missing, and the form could not, therefore, be distinguished from the Devonian form, $P$. pittmani. It was suggested, however, that should further col'ecting yield forms with a welldeveloped umbo, such differences might be found as would justify the erection of a new species-P. sub pittmani. The form originally deseribed was obtained from west of Mt. Uriari, and is in the collection of the Geological Survey.

\section{Kochia striata, sp. nov. (Plate xxi., fig. 8.)}

Kochia, Frech, Die Devonischen Aviculiden Dentschlands, 1891, p. 72; Clarke, New York State Museum, Memoir No. 6. 1904, p. 26, t. 13, f. 1-8.

This form at first sight resembles a eapulid genus, but the shape of the umbilieal region, and its relation to the posterior margin of the shell, together with the presence of a slightlv developed posterior ear, lead to the conclusion that it ought to be placed in Frech's genus, Kochia. The imbo is a little posterior of the

-Annual Rep. Dept. Mines, N.S. W., 1897, p.200. 
median line, incurved and directed anteriorly. On the posterior ear ean be seen a sharp fold along the hinge line. The shell is ornamented by simple and interpolated radial folds spaced eight or ten to a centimetre and traversed by a few faint concentric undulations. The height of the type specimen is $42 \mathrm{~mm}$; the height of the umbo above the hinge-line, 14; the breadth, 35, and the thickness of the single valve is $18 \mathrm{~mm}$.

It was collected by Donald Porter from Swain's Conditional Purchase Lease, seven miles south-east of Carroll, and is in the Museum of the Geological Survey, No. F 1811.

\section{CONOCARDIUM SP. INDET.}

An indefinite shell which has provisionally been referred to this genus is seen in Specimen No. 4424 in the collection of the Geological Survey, obtained by Cullen from the parish of Moorowarra, south of Somerton.

Posidoniella ? spp. indet. (Plate xxiii., fig. 6; Text-fig. $14 a, b$.)

Posidoniella, De Koninck, Faune Calc. Carb. Belg., 1885, p. 184.

These three forms all oceur in the south-east of Babbinboon, and were obtained by Mrs. Scott. The following features are common in the three shells, which are obviously generically related. The shell has a prominent beak or umbo, incurved and place? subcentrally, generally slightly anterior. The hinge line is straight with round angles producing small ears. They are marked with a few (five to eight) prominent ridges, with broad sules between, in which are seen thin radial striae sometimes extending as spines from the margin. The two forms, $\boldsymbol{a}$ and $b$, are rather inflated, but $c$ is much flatter. The shells are rathar like the illustrations of forms of Posidoniella; particularly marked is the resemblance of (a) to Posidoniella subsulcata,* as illustrated by Dr. Wheelton Hind, but they differ from that form in the sub-central character of the umbo and its general prominence above the hinge line. They resemble Athyris royssii to some extent, are the possessors of a lamellar fringe as shown in $b$ (which is the only bilaterally symmetrical form), but differ from it in the presence of so few concentric ridges, and usually asymmetric character and anterior inclination of the umbo Tentatively, however, these forms have been assigned to the genus Posidoniella, awaiting the investigation of further material.

The following are the characters of the three forms:-

(a). This is the form illustrated in Text-fig 14a, and two specimens of it are available. The following are the dimensions of this form:- Height, umbo to margin, 13, $14 \mathrm{~mm}$.; length, 11, $12 \mathrm{~mm}$.; length of hinge line, $9 \mathrm{~mm}$.; height of umbo above hinge, $4 \mathrm{~mm}$.; thickness of valve, $6 \mathrm{~mm}$.; number of concentrie tolds, $7-8$.

The beak in both eases is not quite central, and the middle line is very slightly oblique to the normal to the hinge line. The ears, however, are very nearly equal and the hinge line is straight. The radiating striae are marked.

(b). This also is represented by two specimens, and is proportionately broader than the first. The following are the chief dimensions of the two specimens:Height, 6.5, $6.2 \mathrm{~mm}$.; length, 8, 7.2; length of hinge-line, 5, 4.5; heighะ of umbo above hinge-line, 2.5. 2.5; thickness of valve, $3.7,3.5$.

In both there were five marked eoncentric folds with intervening fine radial markings, which are continued into a fringe along the margin of one of these

•Brit. Carb. Lamell., II. (iii.), 1904, t.25, f.2-6. 
specimens. (The drawing is a composite of the characters of both.) The ears are scarcely developed, the straight hinge-line being broadly rounded on the extremities. These shells appear to be quite symmetrical about the middle line.

$(c)$. The form illustrated in Plate xxiii., fig. 6 , is represented by a single specimen only. The shell is depressed and subquadrate, the lower margin being almost semicircular. The shell is depreșsed, the beak scarcely rising above the hinge line. The anterior ear is marked, but rather smaller than the posterior ear which extends to a sharp terminal angle. The hinge line is straight and slightly oblique to the middle line of the shell. The umbo is subcentral but slightly anterior. There are seven prominent, rather angular, concentric folds crossed by radial striae. No sign of adductor sears is noticeable. The dimensions of this shell are: Height, $10 \mathrm{~mm}$; length, $9 \mathrm{~mm}$.; thickness, $2.5 \mathrm{~mm}$.

The specimens are numbered F:12457 in the collection of the Geological Survey.

\section{Spathella SP. INDET. (Plate xxiii., figs. 5, 7.)}

Spathella, Hall, Geol. New York, Pal. v. (i.), Lamellibranchiata, 1885, p. xxxiii.; Wheelton Hind, Brit. Carb. Lamellibranchiata, ii., 1897, p. 153, t. 23.

There are two specimens which we refer to this genus with some hesitation, seeing that they are certainly specifically distinct from any forms of which we have seen figures. The larger form is an internal east. The shell is elongated, rounded at the terminations, with a sub-anterior umbo, which is narrow and slightly incurved. There are faint traces of concentric growth lines and the anterior adductor scar is strongly marked, but the posterior is faint. The smaller form is almost exactly half the size of the larger, and differs in the marked character of the concentric growth lines giving the shell a lamellar appearance. It is slightly constricted along a band running obliquely from the umbo to the middle of the lower margin. The dimensions of these two shells are as follow:-Length, $(a)$, 32, (b) $15 \mathrm{~mm}$; height, (a) 16, (b) 7; thickness (only one valve), (a) 7, (b) 3 .

The two forms are found on Specimen No. F. 4650 in the collection of the Geological Survey, and were obtained by Cullen from the hills, two miles west of Mount Uriari.

\section{Panenka porteri, sp. nov. (Plate xxi., fig. 10.)}

Panenka, Barrande, Système Sil. Bohême, vi., 1881, p. 128.

This interesting shell is represented by a specimen in the Australian Museum here illustrated, and Specimens 1752-3-4-5 and -7 in the collection of the Geological Survey, obtained by Mr. Donald Porter from Swain's Conditional Purehase, 8 miles south-east of Carroll, and also by No. 1756, from Goonoo Goonoo. 'The form illustrated has a length of $51 \mathrm{~mm}$., and breadth of 57 . The thickness of the single (right) valve is $14 \mathrm{~mm}$. It is folded into numerous simple or interpolated straight, obtusely-rounded, radiating ridges, spaced about ten to the centimetre. There is no concentric ornamentation or imbrication, though there are a few growth lines and concentric undulations placed irregularly. The posterior ear is strongly developed, flange-like, and striated. The umbo is acute, highly incurved and slightly carinate. The posterior adductor sears are high and faintly marked.

Our forms resemble most closely Panenka inultiradiata (Hall), a Devonian form, but are more delicately ornamented than this American type. The umbo is also more acute and ineurved. This form is named in honour of $\mathrm{Mr}$. Douald Porter, the first to make extensive collections of Burindi fossils in this region. 
Entolium aviculatum (Swallow).

Etheridge and Dun, Mem. Geol. Sur. N.S.W., Pal. No. 5, Vol. ii., Pt. 1, 1906, p. 36 , t. 15, f. 1-4 and Bibliography.

This form was obtained by Cullen from Mt. Uriari, near Somerton.

\section{ENTOLIOM SP. INDET.}

An indeterminate form belonging to this genus, represented by Specimen F:4544 in the collection of the Geological Survey.

\section{AVICULOPECTEN SPP. INDET.}

ef. Aviculopecten knockonensis, De Koninck, 1877, Pal. Foss. N.S.W. (1898), p. 232; Aviculopecten granosus, ibid., p. 234, t. 22, f. 10 ; Aviculopecten sp., Etheridge and Dun, Mem. Geol. Sur. N.S.W., Pal. 5, 1904, p. 14, 20, t. 15 , f. $10,11,12$.

Indeterminate forms, which, according to Etheridge and Dun, are not determinable specifically, have been obtained by Cullen from the hills west of Mt. Uriari. Two of these may be similar to the forms which De Koninek compared with $A$. granosus and A. knockonensis respectively, and a third form also is present.

\section{Leiopteria (?) australis Eth. fil.}

Etheridge, Junr., Rec. Geol. Surv. N.S.W., v., 1898, p. 178, t. 19, 1. 19.

This form is represented by Specimens 4539, 4568, 4571 and 4579 in the eollection of the Geological Survey, which were obtained by Cullen in the hills west of Mt. Uriari.

Scaldia sp. indet. (Plate xxi., fig. 9.)

Scaldia, Ryckholt, Mélanges Palaeontologiques, 1852, t. 10, f. 24-26; ibid., 1853, p. 67 .

This form is a cingle right valve, oblong-ovate in shape, with the beak slightly anterior, and the surface ornamented with fine radial striae and delicate concentric growth lines. The shell substance is thin. Its dimensions are: Length of hinge-line, $27 \mathrm{~mm}$.; breadth of valve, 33; height of valve, 27 ; thickness, 11.

It is less elongate than the form described as Scaldia ? depressa by De Koninck,* derived from the Burindi rocks of Buchan on the Gloucester Kiver, and differs also from the Belgian forms described by the same author, and also from the American forms to which we have made reference. It is not, however, sufficiently well preserved for specific description. The specimen is in the collection of the Australian Museum, and was obtained by Mr. Donald Porter from Carroll.

\section{GASTROPODA.}

Ptycomphalus culleni, sp. nov. (Plate xxiii., figs. 12, 14.)

Ptycomphalus, Agassiz, Traduct. Conch. Min. de Sowerby, 1838, p. 222, t. 115, f. $1,2,3$.

The shell is turbinate, elevated and markedly umbilicate, consisting of about five whorls with impressed sutures. The aperture is sub-circular. The slit-band is placed medianly between two prominent ridges, and above the upper of these ridges there are five finer ridges, while below, between the slit-band and the

-Pal. Foss. N.S.W., (1898), p.203, t.15, f.6-7. 
umbilicus, the ridges or spiral striae are more than a seore in number and extend into the umbilicus itself. The faintly marked and delicate growth lines eross these ridges, giving the shell a slight sub-cancellate appearance. Two specimens are available of this form, respectively 4684 and 4642 in the collectien of the Geological Survey. The dimensions of these are: Diameter of base, $29 \mathrm{~mm}$., or in the more complete shell $25 \mathrm{~mm}$. In the latter also the height of the shell is $17 \mathrm{~mm}$; the height of the aperture is $12 \mathrm{~mm}$., and the breadth $14 \mathrm{~mm}$. These forms were collected by Cullen from the Parish of Moorowarra, south of Somerton.

Mourlonia ornata, sp. nov. (Plate xxii., fig. 1.)

Mourlonia, De Koninck, Ann. Mus. Roy. Nat. Hist. Belg., viii., 1883, p. 75.

This beautiful fossil is represented by Specimen No. 4382 in the collection of the Geological Survey, obtained by Cullen from the Parish of Mcorowarra, south of Somerton. The shell is turbinate and elevated, only two whorls are present, the upper part having been broken away. The body whorl is highly distended, oval in eross section, with two marked ridges limiting the narrow slit-band on the periphery. Between these and the upper suture there are four small spiral ridges alternating with four others that are still smaller. On the lower side of the slit-band there are several less distinct ridges. These are traversed by delicate growth lines giving a sub-cancellate appearance. There is a small umbilicus. The dimensions are: Probable height, $25 \mathrm{~mm}$; diameter of base, $21 \mathrm{~mm}$.; height of body whorl, $12 \mathrm{~mm}$; breadth, $13.5 \mathrm{~mm}$.; angie of spire, $70^{\circ}$.

\section{Mourlonia sp. indet. (Text-fig. 15.)}

The forms are turreted, but depressed, the spiral angle being about $95^{\circ}$. They consist of three or four pentagonal whorls with strongly impressed sutures. The upper surfaces of the whorls are excavated and bordered by a stronglyridged shoulder, below which the flattened area of the broad slit-band slopes outwards and downwards to the lower angular ridge, where the whorl bends sharply in towards the umbilicus. Below this, but lying nearer to the periphery than to the centre of the broad flat umbilicus, is a third but very subordinate angular ridge.

The specimens are internal easts only, and do not show the external ornamentation. The dimensions of two specimens are as follow:-Height, 8 mm., 8.5 mm.; diameter, $15 \mathrm{~mm}$., $22 \mathrm{~mm}$; height of aperture, 6,8 ; breadth, $9,10 \mathrm{~mm}$.

These forms of this type were obtained by Mrs. Scott in the south-east of Babbinboon.

\section{Worthenia (?) Canaliculata Eth. fil.}

R. Etheridge, Jun., Rec. Geol. Surv. N.S.W., viii., Pt. 3, 1907, p. 192, t. 38, f. 4.

This specimen was obtained at Carroll by D. A. Porter, and is in the collection of the Geological Survey.

Gosseletina australis var. alta, var. nov. (Plate xxii., figs. 5, 6.)

Gosseletina australis, Etheridge, Junr., Rec. Geol. Sur. N.S.W., ii., 1890, p. 82; ibid., vii., 1907 , p. 192 , t. 37 , f. $6,7,8$; t. 38 , f. 7,8 .

This shell consists of four or five convex whorls; the spire is short and depressed, and the height of the body whorl is slightly greater than the height of the remainder of the shell. It is regularly convex, almost circular in cross sec- 
tion. The slit band is placed nearer to the suture than to the greatest periphery of the shell, but is not preserved in our specimens, a little patch of obliquely striated test from below the slit band serving to indicate its position.

The following are the dimensions of two specimens: Height of spire, 9, 9mm.; diameter of base, 17,21 ; height of aperture, 9,9 ; breadth of aperture, 9,10 ; angle of spire, $115^{\circ}$.

This variety differs from the type of the species in the greater height of the spire proportionately to that of the body whorl. These forms were collected by Mrs. Scott from the south-east of Babbinboon, and are Nos. F 12455 in the collection of the Geological Survey.

\section{Gosseletina Mackayi, sp. nov. (Plate xxii., fig. 2.)}

The spire consists of four or five whorls, the first three being discoid, but the body whorl is depressed so that the top of the aperture rests against the middle line of the previously-formed whorl. The whorls are turreted, with a sharp angle placed half-way between the suture and the periphery and marked by low tubercles. The slit-band is half way between this angle and the suture. The aperture cannot be seen.

The dimensions are: Height of spire, about $16 \mathrm{~mm}$.; diameter of base, 32; beight of body whorl, 11.

The specimen is a east obtained by Mrs. Scott from the shelly ridge in the south-east of Babbinboon, and named after her parents in appreciation of their hospitality and helpfulness. The type is specimen No. F 12456 in the collection of the Geological Survey.

Gosseletixa scotti, sp. nov. (Plate xxii., figs. 3, 4.)

Shell composed of four or five whorls, the cross section of which is very characteristic. The suture is rather deeply marked, and the slit-band lies at a sharp angle close to the suture line, less than a quarter of the distance from the margin to the periphery, and beneath it is another but much fainter ridge. The margin is rounded and subangular. There is a small umbilicus.

Dimensions: Height, $8 \mathrm{~mm}$; breadth of base, 20; height of aperture, 8; breadth of aperture, 9 ; angle of spire, $135^{\circ}$.

This form differs from $G$. australis in its greater size, and the position and angular character of the slit band. It was obtained by Mrs. Scott from the shelly ridge in the south-east of Babbinboon. The type is specimen No. F 12458 in the collection of the Geological Survey.

\section{YvaNia KONINCKII Eth fil.}

Baylea koninckii, Etheridge, Junr., Rec. Geol. Surv. N.S.W., ii., 1890, p. 82; Yvania koninckii, ibid., Geol. Pal. Qld. and N. Guinea, 1892, p. 288, t. 41, f. 7; ibid., Ree. Geol. Surv. N.S.W., viii., 1907, p. 192, t. 38, f. 2, 3.

This form is represented in our region by Specimen 1804 in the collection of the Geological Survey, obtained from Carroll by Donald Porter.

\section{Porcellia pearsi Eth. fil. (Plate xxii., fig. 7.)}

R. Etheridge, Junr., Geol. Pal. Q'sland and N. Guinea, 1892, p. 290, t. 15, f. 7, 8.

This form is represented by Specimen 4376 in the collection of the Geological Survey, and was obtained by Cullen from the parish of Moorowarra. It consists of a cast of the base of a single shell. It contains about four or five 
approximately quadrangular whorls, with rounded angles, the lower exterior angle of each whorl bearing prominent tubercles. The shell is loosely coiled into a low spiral with a very broad umbilicus, the conical angle of which is about $120^{\circ}$. The base is $18 \mathrm{~mm}$. in diameter and the body whorl at the aperture is $6 \mathrm{~mm}$. in diameter.

This species was instituted by Etheridge to include forms obtained from the Star, Gympie, and Middle Bowen Series of Queensland.

Phanerotrema australis, sp. nov. (Plate xxiii., fig. 13; Text-fig. 16.)

Phanerotrema, Fischer, Man. Conchyl., 1887, p. 851.

The shell is depressed, sub-turbinate, and umbilicate, eonsisting of four or five rapidly enlarging whorls, coiled into a laterally compressed or oval spiral. The superior whorls are rounded, but the greatly enlarged body whorl is flattened on the upper portion with a distinct shoulder, at the angle of which is

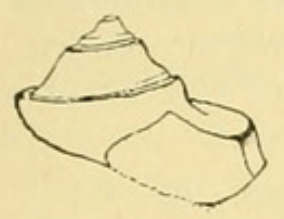

Text-fig.15.-Mourlonia sp. indet. Babbinboon. $\left(\mathrm{x} \frac{4}{3}\right)$.

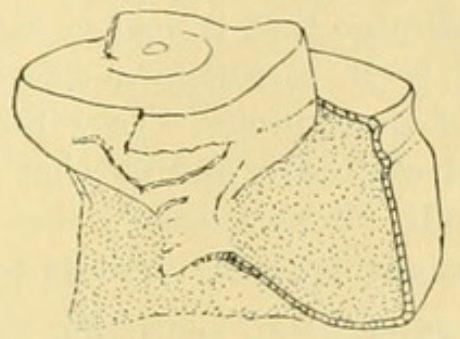

Text-fig.16.-Phanerotrema australis, sp. nov. to show form of body whorl. Babbinboon.
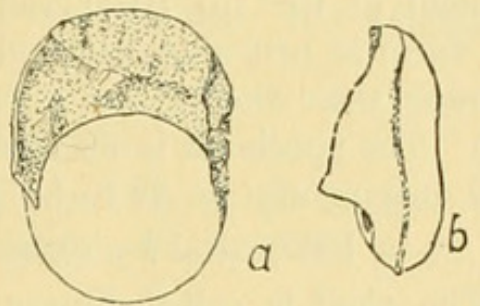

Text-fig-17.-Bellerophon of. hiulcus Martin, and Bellerophon sp. indet. Babbinboon.

situated the slit-band between two ridges. The rounded lower surface of the body whorl passes forward into a sharp lower peripheral angle making a subquadrate aperture. A little of the original test preserved on the original of Text-fig. 16 is composed of three layers, and is marked with very fine growth lines descending obliquely forward just below the slit-band.

Dimensions :

Plate xxiii., fig. $13 . \quad$ Text-fig. 15.

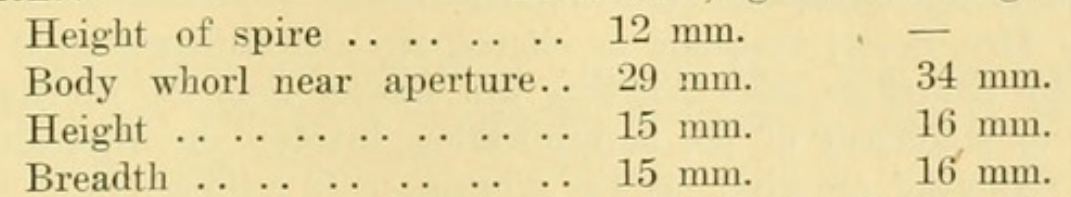

The first of these has an angle of spire of $135^{\circ}$, but the tip of the spire has been broken from the second shell. The first shell is Specimen 4659 in the collection of the Geological Survey; the second was obtained by Mrs. Scott from the south-east of Babbinboon, and is in the collection of the University of Sydney.

Phanerotrema australis var. alta, var. nov. (Plate xxiii., figs. 9, 10.)

This form differs from the type of the species in the more elevated character of the spire, the dimensions being: Height, $25 \mathrm{~mm}$.; breadth, $30 \mathrm{~mm}$.; aperture of whorl, height and breadth, $20 \mathrm{~mm}$. It consists of four whorls with a spiral angle of $110^{\circ}$. In the form studied there was faint evidence of some concentric spiral striae, erossed by growth lines. The form is represented by Specimen 4642 in the collection of the Geological Surrey obtained by Cullen from Moorowarra. 


\section{MURChisonia SP. INDET.}

Forms referable to this genus were obtained by Mr. Pittman from near Carroll.*

\section{BELlerophoN SPP. INDET. (Text-fig. 17.)}

Out of several specimens of Bellerophon collected by Mrs. Scott, east of Babbinboon, two types only appear to be represented. Both are so poorly preserved as to be incapable of specific determination. The larger is broad and oval, the mouth broadly erescentic. The umbilicus (to the right of Text-fig. 17a) is wide and shallow. The upper edge of the lip is thickened, and there seems to be no umbilicus. There is only the faintest indication of a slit-band, and no sign of ornamentation. The height is $13 \mathrm{~mm}$. and greatest diameter 23 . The height of the aperture is $18 \mathrm{~mm}$., and breadth 10 .

This form is evidently elosely related to B. hiulcus (Martin) $\dagger(C f$. Sowerby, Min. Conch., t. 470 , f. 1).

The second form, Text-fig. $17 b$, is narrower and markedly carinate. The fragment of the lip preserved indicates that it had a widely spreading mouth. This form is probably more allied to $B$. costatus, though it is apparently rather narrower than the typical form of that species. (See Sowerby, op. cit., t. 470, f. 4.) The specimen is an internal east only, and no sign of ridging or other external ornamentation is to be found.

Euomphalus carrollensis, sp. nov. (Plate xxii., fig. 9.)

The shell is sub-turbinate to sub-conical, consisting of five to six whorls of which all but the body whorl are sub-circular in cross section, while the latter has a broad flattened upper surface, and is entirely of the pentangulatus type. The ornamentation of the shell consists of numerous growth lines of the normal Euomphalid type. Dimensions: Height of spire, $15 \mathrm{~mm}$; breadth, 33; height of body whorl, 9 ; spire angle, $120^{\circ}$.

The specimen was obtained at Carroll, and is Specimen No. 2771 in the collection of the Geological Survey.

\section{EUOMPHALUS CERA (Eth. fil.).}

R. Etheridge, Jun., Rec. Geol. Surv. N.S.W., vi., 1896, p. 17, t. 1, f. 5, 6.

The specimens examined from the south-east of Babbinbood (which were obtained by Mrs. Scott) resemble in all respects the illustrations of Euomphalus cera given by Etheridge, save that they are smaller than the illustration. As no dimensions or statement of the multiplication involved in illustrating are mentioned, the following are given as the dimensions in millimetres of several forms examined:-

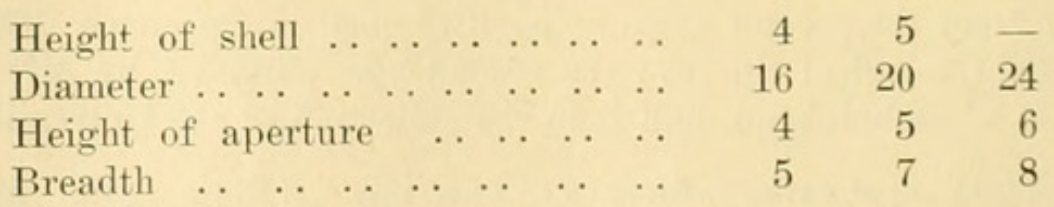

Euomphalus pentangulatus (Sowerby).

J. Sowerby, Min. Conch. Grt. Brit., 1814, p. 97, t. 45, f. 1 and 2; R. Etheridge, Junr., Rec. Geol. Surv. N.S.W., viii., pt. 3, 1907, p. 196, t. 38, f. 1.

The specimen closely resembles that from Moonan Brook, described and figured by Etheridge. Its dimensions are: Height of shell, $9 \mathrm{~mm}$; breadth of shell, 29 ; height of aperture, 7 ; breadth of aperture, 10 .

*Annual Rept. Dept. Mines, N.S.W., 1897, p.200.

+Petref. Derbiensis, 1809, t. 40, f. 4. 
This form is represented by Specimen 4370 in the collection of the Geologieal Survey, obtained by Cullen from Moorowarra Parish, and another from Carroll.

Straparollus davidis, sp. nov. (Plate xxii., fig. 10.)

Straparollus, Montfort, Conch. Syst., Vol. ii., 1810, p. 174.

The form is sub-discoid, and consists of five or six gently enlarging whorls which are sub-cireular in eross section, making a low spiral with an extremely broad umbilicus. The shell is ornamented by transverse striae which cross the whorls almost perpendicularly. The dimensions are: Height of spire, $7 \mathrm{~mm}$; diameter of base, $24 \mathrm{~mm}$.; height of aperture, $5 \mathrm{~mm}$.; breadth, $6 \mathrm{~mm}$.; angle of spire, $135^{\circ}$. This form has no analogy among the Belgian Carboniferous forms described by De Koninck, but is not unlike S. clymenoides (Hall) from the Devonian (Schoharie Grit and Helderberg Series) of the United States. The specimen upon which this species has been instituted is No. F 1773 in the collection of the Geological Survey, and was found at Carroll by Mr. J. G. Griffin. We dedicate the species to Professor David, F.R.S.

\section{Naticopsis brevispira (Ryekholt). (Plate xxii., fig. 8.)}

P. de Ryckholt, Melanges Palaeontol., Pt. i., 1847, p. 78, t. 3, f. 8, 9 (non Roemer); De Koninck, Faune Cale. Carb. Belge, Pt. 3, 1881, p. 22, t. 1, f. $23,24,25,26$.

Several small specimens are available for examination. The spire has four whorls ornamented with fine striae with the same sinuosity as is general for this genus. The form agrees fairly closely with De Koninck's diagnosis, the following being the dimensions of the largest example: Height of spire, $12 \mathrm{~mm}$.; width, 14; height of aperture, 10 ; width, 6 ; spiral angle, $135^{\circ}$.

Some callus occurs on the inner margin, but its tubereular nature cannot be observed. In Belgium this form oceurs in Stage VI. of the Carboniferous Limestone at Visé. That ehosen for illustration is No. 1814 of the Geological Survey, and was obtained at Carroll.

\section{Naticopsis globosa (Hoeninghaus). (Plate xxii., figs. 15, 16.)}

Hoeninghaus, Verzeichniss des von E. W. Hoeninghaus dem Museum der Universitat Bonn uberlassen Petrifacten Sammelung, 1829, p. 8; De Koninck, Faune Calc. Belg., Pt. 3, 1881, p. 15, t. 1, f. 1, 2, 8, 9, 10, 11; t. 2 , f. 25 .

Our specimens are the internal casts of three individuals, one of which has been slightly flattened by erushing parallel to the spire. The spire is composed of four or five whorls. The measurements of the two forms are as follows:-

A.

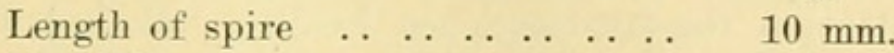

$\begin{array}{llllllllllllll}\text { Breadth } & \ldots & \ldots & \ldots & \ldots & \ldots & \ldots & \ldots & \ldots & \ldots & 10 & \mathrm{~mm} .\end{array}$

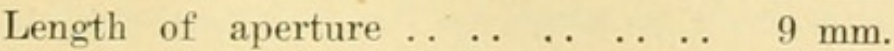

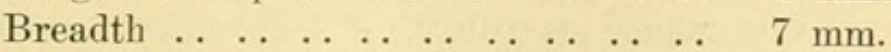

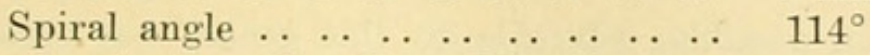

B. (figured).

$17 \mathrm{~mm}$.

$14 \mathrm{~mm}$.

$14 \mathrm{~mm}$.

flattened.

$110^{\circ}$

This form was collected by Mrs. Seott from the S.E. of Babbinboon, and examples are Specimen No. F 12459 in the Museum of the Geological Survey, and two others in the collection of the University of Sydney. 
In Belgium, this form oceurs in Stage VI. of the Carboniferous Limestone at Visé. It is also found at Bolland, in Yorkshire, near Glasgow, and in the Chester Group (Upper Mississippian) in Illinois.

Naticopsis obliqua, sp. nov. (Plaic xxii., figs. 13, 14.)

This form has some resemblance to $N$. consimilis (De Kon.), but differs from it specifically. It is also quite unlike any American form of which we have information. It is an internal cast, the spire consisting of five or six whorls. The last whorl is for the most part below rather than around the preceding whorls. The distinguishing feature is the very eccentric position of the spire in regard to the upper surface of the last whorl.

The dimensions are as follow:- Height of spire, $13 \mathrm{~mm}$; breadth of base, 18 ; height of aperture, 14 ; breadth of aperture, 8 ; angle of spire, $115^{\circ}$.

The specimen was obtained by Mrs. Seott in the south-east of Babbinboon, and is No. F 12460 in the collection of the Geological Survey.

\section{Macrochemus filosus (Sowerby).}

Littorina filosa, Sowerby, in Mitehell's Three Expeditions into Eastern Australia, 1838, p. 15, 38, t. 3, f. 5; Morris, in Strzelecki's Phys. Deser. of N.S.W. and Van Diemen's Land, 1845, p. 285, t. 18, f. 14; Maorocheilus filosus, De Koninck, 1877, Pal. Foss. N.S.W., (1898), p. 264, t. 23, f. 16.

This form was among the first fossils found in the district, and was obtained by Mitehell at Perimbungay, just below the junction of the Peel and Namoi Rivers.

\section{Platyceras SP. indet.}

Specimen 1811 of the collection of the Geological Survey has been referred to this genus. It was obtained near Carroll.

LOXONEMA BABBINBOONENSIS Eth. fil.

Etheridge, Junr., Rec. Geol. Surv. N.S.W., viii., 1907, p. 194, t. 38, f. 5, 6.

This form was collected by Stonier from the parish of Babbinboon, and probably near the south-eastern portion.

\section{LOXONEMA SP. INDET.}

Rec. Geol. Surv. N.S.W., viii., 1907, p. 195, t. 37, f. 4, 5.

This form, according to Etheridge, resembles $L$. lefevrei and other species in ornamentation, but is not identical with any of them. It was obtained by Porter from Carroll.

LOxONEMA SP. INDET. (Plate xxii., figs. 11, 12.)

The specimens figured were obtained by Mrs. Scott from the south-east of Babbinboon. These are greatly weathered examples, possibly of $L$. rugifera.

Specimens of Loxonema, generally in an obscure and imperfect state of preservation, are very abundant in the last-mentioned locality. Mitchell was probably referring to a Loxonema when he mentioned the presence of Terebra in this region. ${ }^{*}$

\section{CONularia SP. INDET.}

An indeterminate form, possibly referable to this genus, was obtained by Benson, four miles east of Currabubula. Another example has been reported from Somerton.

-Three Expeditions into Eastern Australia, i., 1838, p.38. 


\section{Hyolites SP. INDET.}

Specimen 4682 in the collection of the Geological Survey contains an indefinite tapering form that has been referred to this genus. Its occurrence at Carroll has also been reported.

\section{SCAPHOPODA}

\section{Dentalium Sp. INDFt.}

Several indefinite forms, possibly referable to this genus, have been found by Mrs. Scott in the south-east of Babbinboon. The largest of these is quite straight and the remaining portion is $46 \mathrm{~mm}$. in length. It is oval in eross section with diameters of 8.5 and $6.5 \mathrm{~mm}$., tapering to diameters of 4 and $3 \mathrm{~mm}$.

\section{CEPHALOPODA.}

A group of exceedingly imperfectly preserved cephalopods have been obtained from the Somerton-Carroll District, which have been provisionally referred to the following old and comprehensive genera, it being quite impossible to determine them closely and on modern lines.

\section{ORTHOCERAS SP. INDET.}

Specimen 4491 in the collection of the Geological Survey, obtained by Cullen from the Parish of Moorowarra.

\section{Trochoceras SP. INDET.}

Collected by Mr. Pittman at Rangira.

$$
\text { Cyrtoceras Sp. indet. }
$$

Specimen 4682 of the Geological Survey, obtained from Somerton.

$$
\text { Cyrtoceras (? Gyroceras) sp. indet. }
$$
Rangira.

Specimen 1843 of the Geological Survey, obtained by Mr. Pittman at

GOMPHOCERAS SP. INDET.

Specimen 1835 of the Geological Survey from Carroll.

\section{TRILOBITA.}

\section{Phillipsia (?) robusta (Mitchell).}

Phillipsia grandis, Eth. fil., Mem. Geol. Surv. N.S.W., Pal. No. 5, Pt. ii., 1892, p. 128, Text-fig. 5; Phillipsia (?) robusta, J. Mitchell; Proc. Linn. Soc. N.S.W., xliii., 1918 , p. 451 , t. 47 , f. $1,8$.

This form was obtained by Porter at Swain's Conditional Purchase Lease, seven miles south-east of Carroll.

\section{Phillipsia sp. indet.}

A fragment of a small pygidium was obtained by Benson, four miles east of Currabubula. It has unfortunately since been lost. 


\section{$2 \mathrm{BHL}$ Biodiversity Heritage Library}

Dun, W S and Benson, W. N. 1920. "The geology and petrology of the Great Serpentine Belt of New South Wales. Part IX. - The geology, palaeontology and petrography of the Currabubula district, with notes on adjacent regions. Section B - Paleontology." Proceedings of the Linnean Society of New South Wales 45, 337-363. https://doi.org/10.5962/bhl.part.19551.

View This Item Online: https://www.biodiversitylibrary.org/item/24141

DOI: https://doi.org/10.5962/bhl.part.19551

Permalink: https://www.biodiversitylibrary.org/partpdf/19551

\section{Holding Institution}

MBLWHOI Library

\section{Sponsored by}

MBLWHOI Library

\section{Copyright \& Reuse}

Copyright Status: NOT_IN_COPYRIGHT

This document was created from content at the Biodiversity Heritage Library, the world's largest open access digital library for biodiversity literature and archives. Visit BHL at https://www.biodiversitylibrary.org. 